Prepared in cooperation with the National Park Service

\title{
Baseline Groundwater Quality in National Park Units Within the Marcellus and Utica Shale Gas Plays, New York, Pennsylvania, and West Virginia, 2011
}

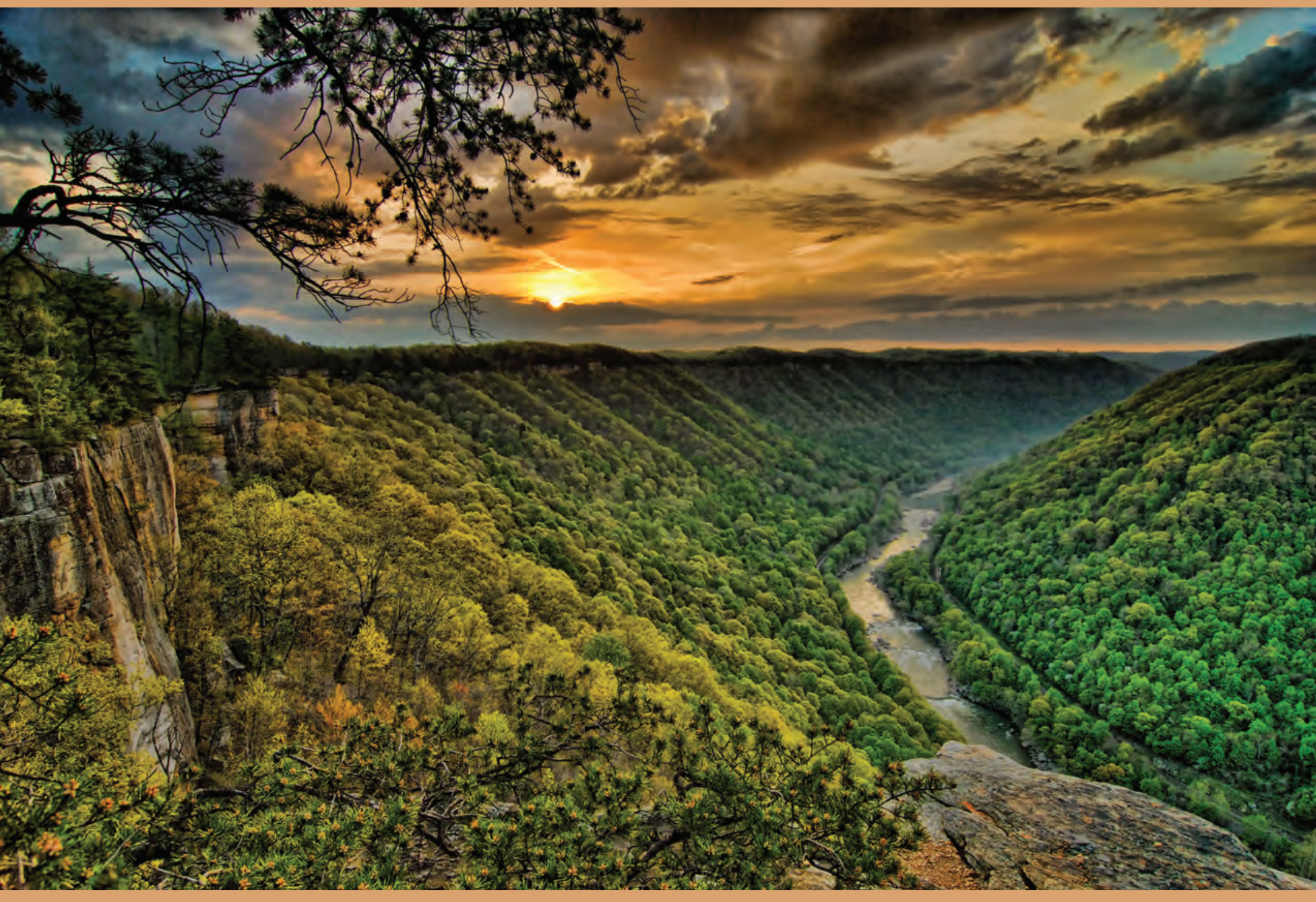

Open-File Report 2012-1150

U.S. Department of the Interior U.S. Geological Survey 
Cover. Sunrise at Diamond Point at New River Gorge National River in West Virginia. (Photograph by Gary Hartley, National Park Service) 


\section{Baseline Groundwater Quality in National Park Units Within the Marcellus and Utica Shale Gas Plays, New York, Pennsylvania, and West Virginia, 2011}

By David A.V. Eckhardt and Ronald A. Sloto

Prepared in cooperation with the National Park Service

Open-File Report 2012-1150 


\title{
U.S. Department of the Interior \\ KEN SALAZAR, Secretary \\ U.S. Geological Survey \\ Marcia K. McNutt, Director
}

\author{
U.S. Geological Survey, Reston, Virginia: 2012
}

For more information on the USGS - the Federal source for science about the Earth, its natural and living resources, natural hazards, and the environment, visit http://www.usgs.gov or call 1-888-ASK-USGS.

For an overview of USGS information products, including maps, imagery, and publications, visit http://www.usgs.gov/pubprod

To order this and other USGS information products, visit http://store.usgs.gov

Any use of trade, firm, or product names is for descriptive purposes only and does not imply endorsement by the U.S. Government.

Although this information product, for the most part, is in the public domain, it also may contain copyrighted materials as noted in the text. Permission to reproduce copyrighted items must be secured from the copyright owner.

Suggested citation:

Eckhardt, D.A., and Sloto, R.A., 2012, Baseline groundwater quality in national park units within the Marcellus and Utica Shale gas plays, New York, Pennsylvania, and West Virginia, 2011: U.S. Geological Survey Open-File Report 2012-1150, 20 p., at http://pubs.usgs.gov/of/2012/1150/. 


\section{Contents}

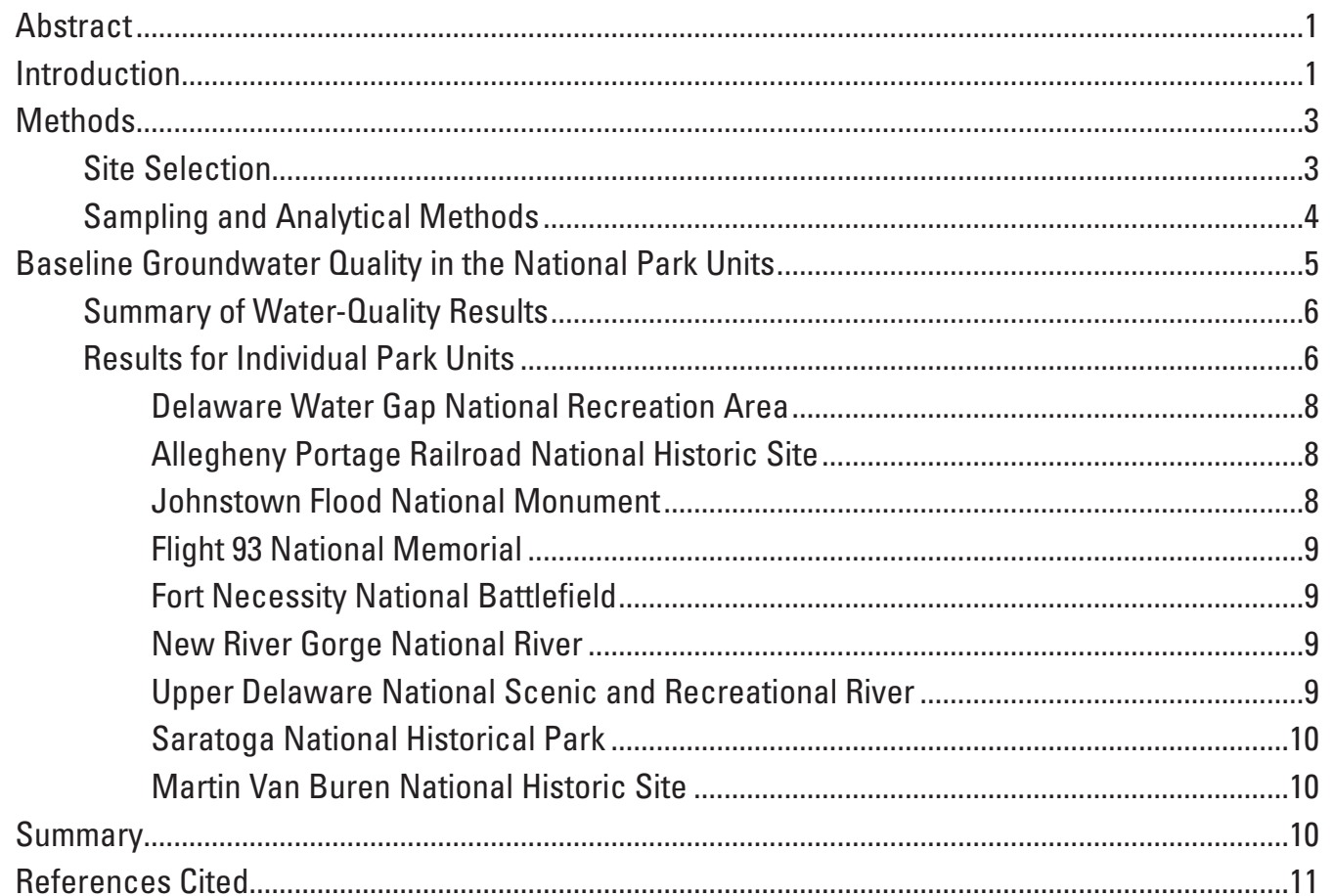

\section{Figure}

1. Map showing location of national park units that were sampled as part of the baseline groundwater-quality assessment in 2011 and the extent of the Marcellus Shale and Utica Shale gas play areas in New York, Pennsylvania, and West Virginia ....2 


\section{Tables}

1. Information on 15 wells and 1 spring sampled at national park units within the Marcellus Shale and Utica Shale in New York, Pennsylvania, and West Virginia in 2011.

2. Summary statistics for concentrations of major ions and properties of samples from 15 wells and 1 spring at national park units within the Marcellus Shale and Utica Shale in New York, Pennsylvania, and West Virginia in 2011.

3. Summary statistics for concentrations of nutrients in samples from 15 wells and 1 spring at national park units within the Marcellus Shale and Utica Shale in New York, Pennsylvania, and West Virginia in 2011

4. Summary statistics for concentrations of trace elements and radioactivity in samples from 15 wells and 1 spring at national park units within the Marcellus Shale and Utica Shale in New York, Pennsylvania, and West Virginia in 2011

5. Summary statistics for physical properties and concentrations of dissolved gases in samples from 15 wells and 1 spring at national park units within the Marcellus Shale and Utica Shale in New York, Pennsylvania, and West Virginia in 2011

6. Physical properties and dissolved gas concentrations for samples from 15 wells and 1 spring at national park units within the Marcellus Shale and Utica Shale in New York, Pennsylvania, and West Virginia in 2011

7. Concentrations of inorganic constituents in samples from 15 wells and 1 spring at national park units within the Marcellus Shale and Utica Shale in New York, Pennsylvania, and West Virginia in 2011

8. Concentrations of nutrients in samples from 15 wells and 1 spring at national park units within the Marcellus Shale and Utica Shale in New York, Pennsylvania, and West Virginia in 2011

9. Concentrations of trace elements and radioactivity in samples from 15 wells and 1 spring at national park units within the Marcellus Shale and Utica Shale in New York, Pennsylvania, and West Virginia in 2011 


\section{Conversion Factors, Datum, and Abbreviations}

\begin{tabular}{|c|c|c|}
\hline Multiply & By & To obtain \\
\hline \multicolumn{3}{|c|}{ Length } \\
\hline foot $(\mathrm{ft})$ & 0.3048 & meter $(\mathrm{m})$ \\
\hline mile (mi) & 1.609 & kilometer $(\mathrm{km})$ \\
\hline \multicolumn{3}{|c|}{ Area } \\
\hline acre & 0.405 & hectare (ha) \\
\hline \multicolumn{3}{|c|}{ Volume } \\
\hline gallon (gal) & 3.785 & liter (L) \\
\hline
\end{tabular}

Temperature in degrees Celsius $\left({ }^{\circ} \mathrm{C}\right)$ may be converted to degrees Fahrenheit $\left({ }^{\circ} \mathrm{F}\right)$ as follows:

$$
{ }^{\circ} \mathrm{F}=\left(1.8 x^{\circ} \mathrm{C}\right)+32
$$

Specific conductance is given in microsiemens per centimeter at 25 degrees Celsius $(\mu \mathrm{S} / \mathrm{cm}$ at $\left.25^{\circ} \mathrm{C}\right)$.

Concentrations of chemical constituents in water are given either in milligrams per liter (mg/L) or micrograms per liter $(\mu \mathrm{g} / \mathrm{L})$.

Horizontal coordinate information is referenced to the North American Datum of 1983 (NAD 83).

\section{Abbreviations}

$\begin{array}{ll}\text { AMCL } & \text { alternative maximum contaminant level } \\ \text { CFC } & \text { chlorofluorocarbon } \\ \text { COD } & \text { chemical oxygen demand } \\ \text { HA } & \text { health advisory for drinking water } \\ \text { MCL } & \text { maximum contaminant level } \\ \text { NB } & \text { national battlefield } \\ \text { NHS } & \text { national historic site } \\ \text { NM } & \text { national monument } \\ \text { NR } & \text { national river } \\ \text { NRA } & \text { national recreation area } \\ \text { NSRR } & \text { national scenic and recreational river } \\ \text { NWIS } & \text { National Water Information System } \\ \text { NWOL } & \text { USGS National Water Quality Laboratory } \\ \text { SMCL } & \text { secondary maximum contaminant level } \\ \text { USEPA } & \text { U.S. Environmental Protection Agency } \\ \text { USGS } & \text { U.S. Geological Survey } \\ \mu \mathrm{m} & \text { micrometer } \\ \mu \mathrm{g} / \mathrm{L} & \text { micrograms per liter } \\ \mathrm{mg} / \mathrm{L} & \text { milligrams per liter } \\ \mu S / \mathrm{cm} & \text { microsiemens per centimeter at 25 degrees Celsius } \\ \text { pCi/L } & \text { picocuries per liter }\end{array}$


THIS PAGE INTENTIONALLY LEFT BLANK 


\title{
Baseline Groundwater Quality in National Park Units Within the Marcellus and Utica Shale Gas Plays, New York, Pennsylvania, and West Virginia, 2011
}

\author{
By David A.V. Eckhardt and Ronald A. Sloto
}

\section{Abstract}

Groundwater samples were collected from 15 production wells and 1 spring at 9 national park units in New York, Pennsylvania, and West Virginia in July and August 2011 and analyzed to characterize the quality of these water supplies. The sample sites generally were selected to represent areas of potential effects on water quality by drilling and development of gas wells in Marcellus Shale and Utica Shale areas of the northeastern United States. The groundwater samples were analyzed for 53 constituents, including nutrients, major inorganic constituents, trace elements, chemical oxygen demand, radioactivity, and dissolved gases, including methane and radon-222.

Results indicated that the groundwater used for water supply at the selected national park units is generally of acceptable quality, although concentrations of some constituents exceeded at least one drinking-water guideline at several wells. Nine analytes were detected in concentrations that exceeded Federal drinking-water standards, mostly secondary standards that define aesthetic properties of water, such as taste and odor. One sample had an arsenic concentration that exceeded the U.S. Environmental Protection Agency maximum contaminant level (MCL) of 10 micrograms per liter $(\mu \mathrm{g} / \mathrm{L})$. The $\mathrm{pH}$, which is a measure of acidity (hydrogen ion activity), ranged from 4.8 to 8.4, and in 5 of the 16 samples, the $\mathrm{pH}$ values were outside the accepted U.S. Environmental Protection Agency secondary maximum contaminant level (SMCL) range of 6.5 to 8.5. The concentration of total dissolved solids exceeded the SMCL of 500 milligrams per liter $(\mathrm{mg} / \mathrm{L})$ at four sites. The sulfate concentration exceeded the SMCL of $250 \mathrm{mg} / \mathrm{L}$ concentration in one sample, and the fluoride concentration exceeded the SMCL of $2 \mathrm{mg} / \mathrm{L}$ in one sample. Sodium concentrations exceeded the U.S. Environmental Protection Agency drinking water health advisory of $60 \mathrm{mg} / \mathrm{L}$ at four sites. Iron concentrations exceeded the SMCL of $300 \mu \mathrm{g} / \mathrm{L}$ in two samples, and manganese concentrations exceeded the SMCL of $50 \mu \mathrm{g} / \mathrm{L}$ in five samples. Radon-222 concentrations exceeded the proposed U.S. Environmental Protection Agency MCL of 300 picocuries per liter in eight samples.

\section{Introduction}

New advances in horizontal drilling and hydraulic fracturing for natural gas development have made the Marcellus Shale and Utica Shale formations a large, exploitable natural gas resource in the northeastern United States (fig. 1). Gas production is being accelerated in States within the shale gas areas due to national energy security needs and the potential economic benefits (Kerr, 2010). In order to produce natural gas from a low-permeability rock such as shale, permeable flowpaths for the gas to move to the well bore must be created in the tight gas-bearing formations through use of high-pressure hydraulic fracturing. Hydraulic fracturing for a gas well drilled horizontally in shale uses substantial volumes of water and chemical additives, often in excess of 1 million gallons, and much of the injected fluid may flow back to the surface through the well bore and casing (Soeder and Kappel, 2009). Fluids that return to the surface during hydraulic fracturing ("flowback") in the Marcellus Shale can have elevated levels of total dissolved solids (TDS), naturally occurring radioactive material (NORM), and other contaminants including arsenic and barium (Palmerton Group, Inc., 2011). Thus, large volumes of drilling and hydraulic fracturing fluids, drill cuttings, and formation water from shale formations will require careful handling, treatment, and disposal. While Federal and State regulations can largely minimize water-quality contamination issues, shale gas production activities may potentially lead to the contamination of water resources in some areas (Kargbo and others, 2010; Kerr, 2010; U.S. Environmental Protection Agency, 2011b).

Recent information from water-quality analyses of flowback fluid from gas wells drilled in the Marcellus Shale in Pennsylvania indicates that these fluids can contain concentrations as high as 290,000 milligrams per liter (mg/L) of TDS, 105,000 mg/L of chloride, $50,200 \mathrm{mg} / \mathrm{L}$ of sodium, and 7,090 mg/L of barium (Palmerton Group, Inc., 2011; updated by Hayes (2011) and Keister (2010)). Radioactivity levels higher than the drinking water standard of 5 picocuries per liter $(\mathrm{pCi} / \mathrm{L})$ have been documented for brine produced from gas wells in New York, where the levels of radium-226 were $16,030 \mathrm{pCi} / \mathrm{L}$, gross-alpha 


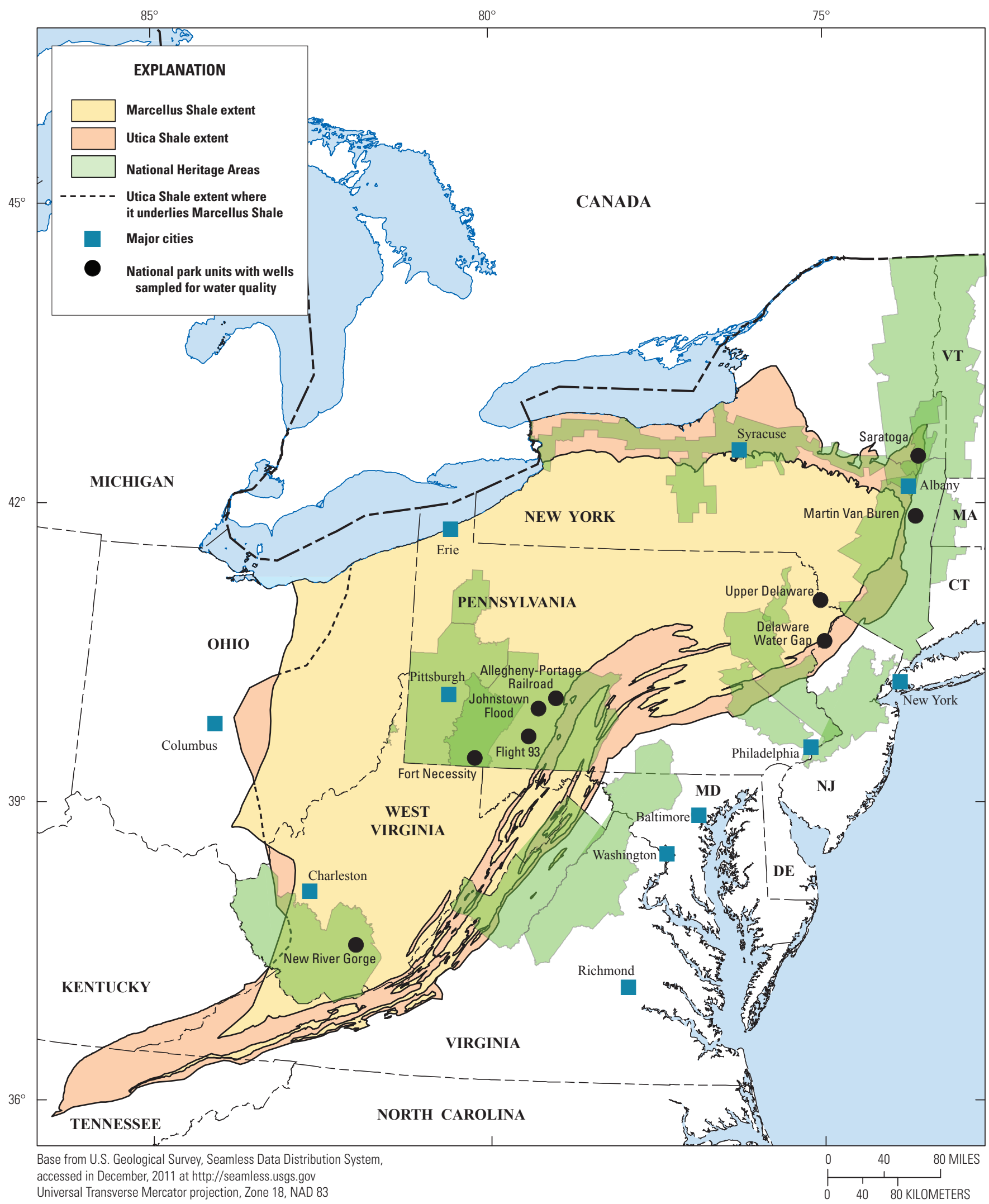

Figure 1. Location of national park units that were sampled as part of the baseline groundwater-quality assessment in 2011 and the extent of the Marcellus Shale and Utica Shale gas play areas in New York, Pennsylvania, and West Virginia. 
particles were $123,000 \mathrm{pCi} / \mathrm{L}$, and gross-beta particles were $12,000 \mathrm{pCi} / \mathrm{L}$ for a well in Schuyler County (New York State Department of Environmental Conservation, 2011). Methane gas concentrations have apparently increased in some watersupply wells through gas migration in subsurface fractures from nearby gas well activities in Pennsylvania (Osborn and others, 2011). In 2008 and 2009, concentrations of TDS periodically exceeded the drinking water standard of $500 \mathrm{mg} / \mathrm{L}$ in Pennsylvania's Monongahela River, which supplies water to approximately 350,000 people; in response, the Pennsylvania Department of Environmental Protection ordered wastewater facilities that discharge to the river to restrict their intake of drilling waste water (Pennsylvania Department of Environmental Protection, 2008).

The National Park Service and regional publicwater-supply and water-management agencies, such as the Susquehanna River Basin Commission and the Delaware River Basin Commission, have a need for water-quality data to evaluate the potential impact of shale gas development on the water resources they manage for the public. Production wells and springs that are used for drinking water within national park units in the shale gas play areas may be susceptible to potential contamination. Of the 30 national park units within the Marcellus Shale and Utica Shale gas play region, more than half are within "fairway" areas that are most likely to experience gas drilling and hydraulic fracturing development.

Groundwater is used in many of these parks as the primary water supply for park staff and visitors. Most groundwater sources at the parks have not been assessed for waterquality constituents that may be associated with hydraulic fracturing activities. Without baseline data for associated water-quality constituents, it is not possible to evaluate possible connections between gas production activities and the well-water chemistry that might be affected.

The objective of this report is to characterize the existing water quality and radiochemistry of national park unit production wells and springs as drilling activities commence in the shale gas play areas of New York, Pennsylvania, and West Virginia. This water-quality characterization of the national park wells and springs provides a baseline of information for chemical and radiochemical constituents to assess if contamination from drilling and gas development occurs. Baseline data for one park (Martin Van Buren National Historic Site), which lies just outside the Utica Shale play area, also are included.

\section{Methods}

Water samples were collected from 15 production wells and 1 spring at 9 national park units in New York, Pennsylvania, and West Virginia in July and August 2011 and analyzed to characterize their physical and chemical quality (table 1). Samples were analyzed for 53 constituents, including nutrients, major inorganic constituents, trace elements, chemical oxygen demand, radioactivity, and dissolved gases, including methane and radon-222. Two samples, one field blank and one replicate sample, were also collected for quality assurance and quality control (QA/QC).

\section{Site Selection}

Contact was made with each park superintendent within the study area for water-supply information regarding sources, location, characteristics, water use, and sampling accessibility. Because of the large number of wells identified as potential candidate sampling sites in the Delaware Water Gap and Upper Delaware units, sample sites were selected based on the importance and use of each well. A total of 16 groundwater sources were selected for sampling within 9 national park units (table 1), largely within the Appalachian Plateau and the Appalachian Valley and Ridge Provinces (Sevon, 2000). Seven of the nine park units are within national heritage areas, where Congress has designated the natural, cultural, and historic resources as nationally important landscapes (fig. 1).

Thirteen of the wells were constructed in bedrock aquifers, with well depths that ranged from 193 to 400 feet (ft) (table 1); these wells typically have a steel casing set into competent bedrock, and water yields are obtained by flow from bedrock fractures intersected by the open borehole. The bedrock aquifers in the study consist of relatively flat-lying, interbedded sedimentary units of shale, siltstone, sandstone, coal, limestone, dolostone, and evaporites of Paleozoic age (Broughton and others, 1962; Cardwell and others, 1968; Berg and others, 1980). The well in Saratoga National Historical Park tapped water through a shallow (28-ft-deep) well screen that was set in an unconsolidated glacial-lake sand aquifer that is highly susceptible to contamination. One well at Delaware Water Gap National Recreation Area (DEWA-3) is cased to $192 \mathrm{ft}$ and open to a sand and gravel deposit at the end of the steel casing. The spring sampled at Fort Necessity National Battlefield is also susceptible to contamination. In addition to contaminants from human activities, groundwater may contain naturally derived elements that can diminish water quality, such as sodium, chloride, sulfate, iron, manganese, and trace elements such as arsenic; some aquifers may also contain natural gas (methane, hydrogen sulfide, and radon) from geologic sources (Molofsky and others, 2011).

The Marcellus Shale of Devonian age is a regionally continuous and commonly identified bedrock geologic unit. The Marcellus crops out at land surface in upstate New York, and the unit gently dips to the south at the rate of about 50 feet per mile under the Appalachian Plateau. The unit is at depths of about 3,000 to 4,000 $\mathrm{ft}$ at the border of Pennsylvania and New York (Martin and others, 2004). Further to the south and west, the Marcellus Shale is present at even greater and more variable depth as the bedrock sequence is influenced by folding in the Ridge and Valley Province in Pennsylvania and West Virginia (Harper, 2008; Harper and Kostelnik, 2010). The thickness of the Marcellus Shale ranges from about $300 \mathrm{ft}$ 
Table 1. Information on 15 wells and 1 spring sampled at national park units within the Marcellus Shale and Utica Shale in New York, Pennsylvania, and West Virginia in 2011.

[Well locations are shown in figure 1. --, information not available]

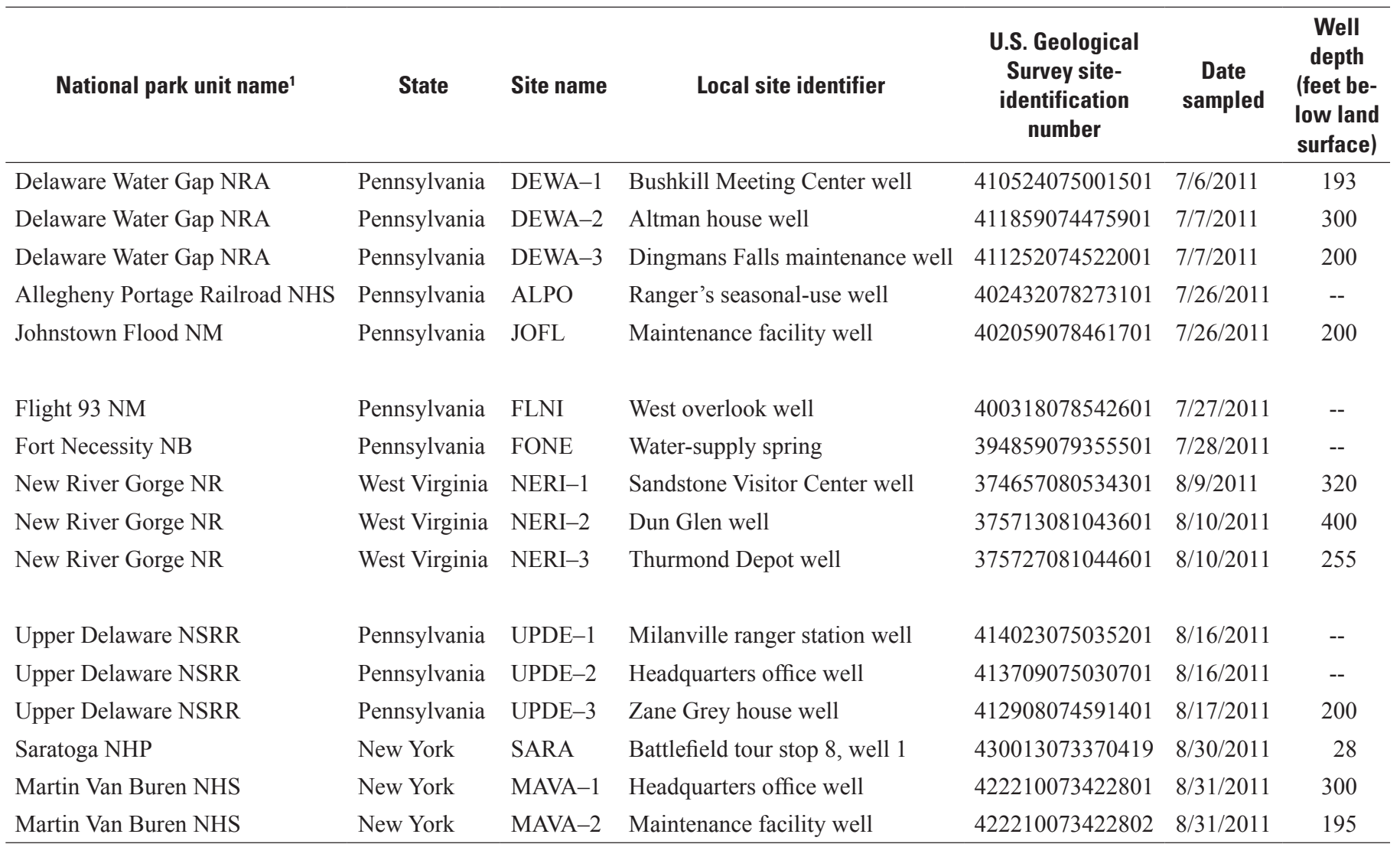

${ }^{1}$ NRA, National Recreation Area; NHS, National Historic Site; NM, National Monument; NB, National Battlefield; NR, National River; NSRR, National Scenic and Recreational River; NHP, National Historical Park.

in northeastern Pennsylvania to less than $50 \mathrm{ft}$ in southwestern West Virginia and Ohio.

The Utica Shale of Ordovician age lies a few thousand feet under the Marcellus Shale in New York, Pennsylvania, Ohio, and West Virginia and extends under adjacent parts of Ontario and Quebec in Canada and Kentucky, Maryland, Tennessee, and Virginia in the United States. The Utica Shale has recently become the target of natural gas exploration in Pennsylvania where it is at a depth of about $8,000 \mathrm{ft}$. The thickness of the Utica Shale ranges from less than $70 \mathrm{ft}$ in Ohio and western West Virginia to $1,000 \mathrm{ft}$ in eastern New York.

\section{Sampling and Analytical Methods}

Scientists from the U.S. Geological Survey (USGS) sampled the individual water-supply sources for the national park units using standard USGS field-sampling protocols. Samples were collected at an untreated tap, typically at a pressure tank and before any filtration, water softening, or bacteriological treatment. Water samples were analyzed for physical properties, inorganic major constituents, nutrients, trace elements, chemical oxygen demand, gross alpha and beta radioactivity, and dissolved gases. The samples were collected and processed from each well or spring for these analyses by methods described in USGS manuals for the collection of water-quality data (Wilde and others, 2004; U.S. Geological Survey, variously dated).

Sampling was done at all well sites by the following steps. The existing submersible well pump was turned on and allowed to run until at least three casing volumes of well water had passed the sampling point. A raw-water tap between the well and the pressure tank was opened, and the water was allowed to flush for several minutes to ensure that the water was representative of the aquifer. Samples were collected through a short piece of silicone tubing attached to the raw-water tap, which avoided all water-treatment systems. Sampling was done at the spring site by the following steps: water was collected in a 5-gallon bucket from the pipe providing flow to an underground sump; water was pumped from the 
Table 2. Summary statistics for concentrations of major ions and properties of samples from 15 wells and 1 spring at national park units within the Marcellus Shale and Utica Shale in New York, Pennsylvania, and West Virginia in 2011.

[All samples represent filtered water. No., number; $\mathrm{mg} / \mathrm{L}$, milligrams per liter; $\mathrm{CaCO}_{3}$, calcium carbonate; --, not applicable; USEPA, U.S. Environmental Protection Agency]

\begin{tabular}{|c|c|c|c|c|c|}
\hline \multirow{2}{*}{ Constituent } & \multirow{2}{*}{$\begin{array}{c}\text { Drinking-water } \\
\text { standard }\end{array}$} & \multirow{2}{*}{$\begin{array}{c}\text { No. of samples } \\
\text { exceeding standard }\end{array}$} & \multicolumn{3}{|c|}{ All 16 samples } \\
\hline & & & Minimum & Median & Maximum \\
\hline \multicolumn{6}{|c|}{ Cations } \\
\hline Calcium, mg/L & -- & -- & 1.04 & 21.3 & 106 \\
\hline Magnesium, mg/L & -- & -- & .253 & 4.00 & 39.7 \\
\hline Potassium, mg/L & -- & -- & .33 & .89 & 3.06 \\
\hline Sodium, mg/L & ${ }^{1} 60$ & 4 & 1.34 & 50.2 & 248 \\
\hline \multicolumn{6}{|c|}{ Anions } \\
\hline Bicarbonate, $\mathrm{mg} / \mathrm{L}$ & -- & -- & 20 & 153 & 423 \\
\hline Bromide, mg/L & -- & -- & $<.01$ & .03 & 1.52 \\
\hline Chloride, $\mathrm{mg} / \mathrm{L}$ & ${ }^{2} 250$ & 0 & .59 & 27.2 & 218 \\
\hline Fluoride, mg/L & ${ }^{2} 2$ & 1 & $<.04$ & .11 & 2.33 \\
\hline Sulfate, $\mathrm{mg} / \mathrm{L}$ & 2250 & 1 & .12 & 9.78 & 304 \\
\hline \multicolumn{6}{|c|}{ Other } \\
\hline Hardness, $\mathrm{mg} / \mathrm{L}$ as $\mathrm{CaCO}_{3}$ & -- & -- & 3.73 & 71.4 & 398 \\
\hline Alkalinity, $\mathrm{mg} / \mathrm{L}$ as $\mathrm{CaCO}_{3}$ & -- & -- & 16 & 126 & 347 \\
\hline Total dissolved solids, $\mathrm{mg} / \mathrm{L}$ & ${ }^{2} 500$ & 4 & 62 & 194 & 691 \\
\hline
\end{tabular}

${ }^{1}$ USEPA drinking water health advisory (taste threshold).

${ }^{2}$ USEPA secondary maximum contaminant level.

bucket with a peristaltic pump through a short piece of silicone tubing. The water was analyzed with a multiprobe meter for physical properties (temperature, specific conductance, dissolved-oxygen concentration, and $\mathrm{pH}$ ). After the measurements of these properties had stabilized, pre-rinsed sample bottles were filled according to standard protocols.

The analyses for physical properties, chemical oxygen demand (COD), radioactivity, and dissolved gases were done on unfiltered water samples to obtain total concentrations. Samples for dissolved concentrations of nutrients, major inorganic constituents, and trace elements were filtered through a pre-rinsed 0.45 -micrometer $(\mu \mathrm{m})$ cellulose capsule filter. To prevent sample degradation, sulfuric acid was added to the COD samples, and nitric acid was added to the major ion and trace-element samples. Samples for radon analysis were obtained through an inline septum with a gas-tight syringe to avoid atmospheric contact. Samples for dissolved gases were obtained through tubing that was placed in glass bottles that were filled and stoppered while submerged in a 5-liter beaker of pumped water to avoid atmospheric contact.

The samples were stored on ice in coolers and shipped by overnight delivery to the following three laboratories: (1) the USGS National Water Quality Laboratory in Denver, Colorado, for analysis of inorganic major constituents, nutrients, trace elements, COD, and radon-222; (2) a USGS contract laboratory in California for analysis of gross alpha and beta radioactivity; and (3) the USGS Chlorofluorocarbon (CFC) Laboratory in Reston, Virginia, for analysis of methane and other dissolved gases. Descriptions of analytical methods for all constituents except the dissolved gases are available through the U.S. Geological Survey (2011); the methods for determination of dissolved gases in water are described by the U.S. Geological Survey (2009). The analytical results are available through the USGS National Water Information System (U.S. Geological Survey, 2012).

\section{Baseline Groundwater Quality in the National Park Units}

The analytical results for the 16 groundwater samples collected during this study are summarized in tables 2 through 5 , and the individual sample results are listed in tables 6 through 9 (at the end of the report). The quality of the sampled groundwater was generally within U.S. Environmental Protection Agency (USEPA) guidelines, although in some samples, the concentrations of certain constituents exceeded Federal drinking-water standards (U.S. Environmental Protection Agency, 2006, 2011a). In general, most of the water-quality 
Table 3. Summary statistics for concentrations of nutrients in samples from 15 wells and 1 spring at national park units within the Marcellus Shale and Utica Shale in New York, Pennsylvania, and West Virginia in 2011.

[All samples represent filtered water except as noted. No., number; mg/L, milligrams per liter; --, not applicable; <, less than; N, nitrogen; P, phosphorus; USEPA, U.S. Environmental Protection Agency]

\begin{tabular}{|c|c|c|c|c|c|}
\hline \multirow{2}{*}{ Constituent } & \multirow{2}{*}{$\begin{array}{l}\text { Drinking-water } \\
\text { standard }\end{array}$} & \multirow{2}{*}{$\begin{array}{l}\text { No. of samples } \\
\text { exceeding limit }\end{array}$} & \multicolumn{3}{|c|}{ All 16 samples } \\
\hline & & & Minimum & Median & Maximum \\
\hline Nitrate plus nitrite, $\mathrm{mg} / \mathrm{L}$ as $\mathrm{N}$ & ${ }^{1} 10$ & 0 & $<.02$ & .05 & 1.16 \\
\hline Nitrite, $\mathrm{mg} / \mathrm{L}$ as $\mathrm{N}$ & ${ }^{1} 1$ & 0 & $<.001$ & $<.001$ & .003 \\
\hline
\end{tabular}

${ }^{1}$ USEPA maximum contaminant level.

problems involve aesthetic considerations, such as taste or odor from excessive dissolved solids, iron, manganese, sodium, and sulfate that develop from natural interactions of water and rock minerals in the subsurface.

The QA/QC field-blank sample contained no constituent in concentrations greater than the laboratory reporting levels, except trace concentrations of total nitrogen $(0.08 \mathrm{mg} / \mathrm{L})$, silica $(0.04 \mathrm{mg} / \mathrm{L})$, cobalt $[0.12$ microgram per liter $(\mu \mathrm{g} / \mathrm{L})]$, and manganese $(0.2 \mu \mathrm{g} / \mathrm{L})$; this indicates that little to no contamination occurred through the sampling or analytical procedures. The results of analysis of the QA/QC replicate sample indicate that variability in sample results was within established limits. The analytes with the largest percent differences between concentration in the groundwater sample and its replicate were low-concentration trace elements (concentrations near the laboratory reporting level for the elements).

\section{Summary of Water-Quality Results}

The results indicate that groundwater used for water supply at the selected national park units is generally of acceptable quality, although concentrations of some constituents exceeded at least one drinking-water standard at several wells. Specific conductance of the samples, which is an indication of the dissolved mineral content, ranged from 105 to 1,160 microsiemens per centimeter $(\mu \mathrm{S} / \mathrm{cm})$ at 25 degrees Celsius (tables 5 and 6). Calcium and magnesium contribute to water hardness, and 5 of the 16 samples had hardness greater than $180 \mathrm{mg} / \mathrm{L}$ (table 7), which is classified as "very hard" (Hem, 1985). Nutrient concentrations were low (tables 3 and 8), and no sample had a detectable chemical oxygen demand (table 6), which indicates that sources of organic waste are minimal at the sampled sites. Gross alpha and gross beta radioactivity levels were low; maximum activities were 3.6 and $3.3 \mathrm{pCi} / \mathrm{L}$, respectively (tables 4 and 9). Dissolved methane gas concentrations ranged from nondetected to $30.1 \mathrm{mg} / \mathrm{L}$ (tables 5 and 6). These methane concentrations, except for the one sample with a concentration of $30.1 \mathrm{mg} / \mathrm{L}$, are considered to be within ambient background levels (Eltschlager and others, 2001; Osborn and others, 2011).

Nine analytes were detected in concentrations that exceeded Federal drinking-water standards (tables 2-5). The $\mathrm{pH}$ of the samples (tables 5 and 6) ranged from 4.8 to 8.4 , and the levels of 5 of the 16 samples were outside the accepted secondary maximum contaminant level (SMCL) range of 6.5 to 8.5 (U.S. Environmental Protection Agency, 2011a). One sample (tables 4 and 9) had an arsenic concentration that exceeded the USEPA maximum contaminant level (MCL) of $10 \mu \mathrm{g} / \mathrm{L}$ (U.S. Environmental Protection Agency, 2011a). The concentration of total dissolved solids exceeded the SMCL of $500 \mathrm{mg} / \mathrm{L}$ in four samples (tables 2 and 7). The sulfate concentration exceeded the SMCL of $250 \mathrm{mg} / \mathrm{L}$ concentration in one sample (tables 2 and 7), and the fluoride concentration exceeded the SMCL of $2 \mathrm{mg} / \mathrm{L}$ in one sample (tables 2 and 7). The USEPA health advisory (HA) for sodium, which recommends that concentrations in drinking water not exceed $60 \mathrm{mg} / \mathrm{L}$ to minimize the taste, was exceeded in four samples (tables 2 and 7; U.S. Environmental Protection Agency, 2002, 2006). Iron concentrations exceeded the SMCL of $300 \mu \mathrm{g} / \mathrm{L}$ in two samples (tables 4 and 9), and manganese exceeded the SMCL of $50 \mu \mathrm{g} / \mathrm{L}$ in five samples (tables 4 and 9). Radon222 exceeded the proposed USEPA MCL of $300 \mathrm{pCi} / \mathrm{L}$ in eight samples (tables 4 and 9; U.S. Environmental Protection Agency, 2004).

\section{Results for Individual Park Units}

A brief description of the water-supply sources and the individual water-quality results at the nine park units follows. The water-quality results are presented in tables 6 through 9 . 
Table 4. Summary statistics for concentrations of trace elements and radioactivity in samples from 15 wells and 1 spring at national park units within the Marcellus Shale and Utica Shale in New York, Pennsylvania, and West Virginia in 2011.

[All concentrations in micrograms per liter except as noted. All samples filtered except as noted. No., number; <, less than; --, not applicable; pCi/L, picocuries per liter; mrem/yr, millirem per year; USEPA, U.S. Environmental Protection Agency]

\begin{tabular}{|c|c|c|c|c|c|}
\hline \multirow{2}{*}{ Constituent } & \multirow{2}{*}{$\begin{array}{l}\text { Drinking-water } \\
\text { standard }\end{array}$} & \multirow{2}{*}{$\begin{array}{l}\text { No. of samples } \\
\text { exceeding standard }\end{array}$} & \multicolumn{3}{|c|}{ All 16 samples } \\
\hline & & & Minimum & Median & Maximum \\
\hline Aluminum & ${ }^{3} 50$ & 0 & $<1.7$ & $<1.7$ & 27.9 \\
\hline Antimony & ${ }^{1} 6$ & 0 & $<0.03$ & $<0.03$ & .11 \\
\hline Arsenic & ${ }^{1} 10$ & 1 & $<.02$ & .16 & 32.3 \\
\hline Barium & 12,000 & 0 & 3 & 48 & 1,050 \\
\hline Beryllium & ${ }^{1} 4$ & 0 & $<.01$ & $<.01$ & .02 \\
\hline Boron & -- & -- & $<3$ & 38 & 307 \\
\hline Cadmium & ${ }^{15}$ & 0 & $<.02$ & $<.02$ & .08 \\
\hline Chromium & ${ }^{1} 100$ & 0 & $<.06$ & $<.06$ & .33 \\
\hline Cobalt & -- & -- & $<.02$ & .04 & 55.1 \\
\hline Copper & ${ }^{3} 1,000$ & 0 & $<.05$ & -- & 16.2 \\
\hline Iron & 3300 & 2 & $<3$ & 21 & 8,340 \\
\hline Lead & ${ }^{2} 15$ & 0 & $<.01$ & .17 & 2.94 \\
\hline Lithium & -- & -- & .06 & 8.9 & 98.4 \\
\hline Manganese & ${ }^{3} 50$ & 5 & .04 & 8.9 & 3,320 \\
\hline Molybdenum & -- & -- & $<.01$ & .13 & 2.53 \\
\hline Nickel & -- & -- & $<.09$ & .18 & 76.2 \\
\hline Selenium & ${ }^{1} 50$ & 0 & $<.03$ & -- & .3 \\
\hline Silver & ${ }^{1} 100$ & 0 & $<.01$ & $<.01$ & $<.01$ \\
\hline Strontium & -- & -- & 43.3 & 293 & 1,210 \\
\hline Thallium & 12 & 0 & $<.01$ & $<.01$ & $<.01$ \\
\hline Vanadium & -- & -- & $<.08$ & $<.08$ & .4 \\
\hline Uranium & 130 & 0 & $<.004$ & .02 & 1.75 \\
\hline Zinc & ${ }^{3} 5,000$ & 0 & $<1.4$ & 4.6 & 342 \\
\hline Gross alpha radioactivity, $\mathrm{pCi} / \mathrm{L}$, unfiltered & ${ }^{1} 15$ & 0 & $<.8$ & $<.8$ & 3.6 \\
\hline Gross beta radioactivity, $\mathrm{pCi} / \mathrm{L}$, unfiltered & ${ }^{1} 4 \mathrm{mrem} / \mathrm{yr}$ & -- & $<.8$ & .9 & 3.3 \\
\hline Radon-222, pCi/L, unfiltered & ${ }^{4} 300$ & 8 & 54 & 340 & 3,030 \\
\hline
\end{tabular}

${ }^{1}$ USEPA maximum contaminant level.

${ }^{2}$ USEPA treatment technique action level.

${ }^{3}$ USEPA secondary maximum contaminant level.

${ }^{4}$ USEPA proposed maximum contaminant level. 
Table 5. Summary statistics for physical properties and concentrations of dissolved gases in samples from 15 wells and 1 spring at national park units within the Marcellus Shale and Utica Shale in New York, Pennsylvania, and West Virginia in 2011.

[All samples represent unfiltered water. No., number; $\mu \mathrm{S} / \mathrm{cm}$, microsiemens per centimeter at 25 degrees Celsius; mg/L, milligrams per liter; --, not applicable; USEPA, U.S. Environmental Protection Agency]

\begin{tabular}{|c|c|c|c|c|c|}
\hline \multirow{2}{*}{ Property or constituent } & \multirow{2}{*}{$\begin{array}{l}\text { Drinking-water } \\
\text { standard }\end{array}$} & \multirow{2}{*}{$\begin{array}{l}\text { No. of samples } \\
\text { exceeding limit }\end{array}$} & \multicolumn{3}{|c|}{ All 16 samples } \\
\hline & & & Minimum & Median & Maximum \\
\hline $\mathrm{pH}$ & ${ }^{1} 6.5-8.5$ & 5 & 4.8 & 6.7 & 8.4 \\
\hline Specific conductance, $\mu \mathrm{S} / \mathrm{cm}$ & -- & -- & 105 & 347 & 1,160 \\
\hline Oxygen, $\mathrm{mg} / \mathrm{L}$ & -- & -- & $<0.2$ & 1.4 & 10.7 \\
\hline Methane, mg/L & 228 & 1 & $<0.001$ & 0.001 & 30.1 \\
\hline Argon, mg/L & -- & -- & 0.62 & 0.75 & 1.1 \\
\hline Nitrogen, mg/L & -- & -- & 15.3 & 20.7 & 40.1 \\
\hline Carbon dioxide, $\mathrm{mg} / \mathrm{L}$ & -- & -- & 0.23 & 11.4 & 91.8 \\
\hline
\end{tabular}

${ }^{1}$ USEPA secondary maximum contaminant level.

${ }^{2}$ Office of Surface Mining recommended action level (Eltschlager and others, 2011).

\section{Delaware Water Gap National Recreation Area}

The Delaware Water Gap National Recreation Area (DEWA) preserves 70,000 acres along 40 miles (mi) of the Delaware River above the Delaware Water Gap in eastern Pennsylvania. The park provides opportunities for visitors to canoe, hike, camp, swim, picnic, bicycle, cross country ski, fish, and hunt. Two bedrock wells, the Bushkill Meeting Center well (DEWA-1) and the Altman House well (DEWA2), and one well in an unconsolidated sand and gravel aquifer, the Dingmans Falls maintenance well (DEWA-3), were sampled in July 2011. DEWA-1 is in Devonian limestone and chert, and DEWA-2 is in Devonian shale and siltstone. DEWA-1 had the highest uranium concentration $(1.75 \mu \mathrm{g} / \mathrm{L})$ and the highest gross alpha activity $(3.6 \mathrm{pCi} / \mathrm{L})$ of all 16 samples collected for this study; neither result, however, exceeded drinking-water standards. DEWA-3 had the highest dissolved oxygen $(10.7 \mathrm{mg} / \mathrm{L})$ concentration of all 16 samples and also exceeded the proposed USEPA MCL for radon $(610 \mathrm{pCi} / \mathrm{L})$. Water from DEWA-1 exceeded the USEPA SMCL for manganese $(85.2 \mu \mathrm{g} / \mathrm{L})$. The water from DEWA-2 is soft $\left[17.4 \mathrm{mg} / \mathrm{L}\right.$ as calcium carbonate $\left.\left(\mathrm{CaCO}_{3}\right)\right]$, water from DEWA-3 is moderately hard $\left(81.9 \mathrm{mg} / \mathrm{L}\right.$ as $\left.\mathrm{CaCO}_{3}\right)$, and water from DEWA-1 is hard $\left(165 \mathrm{mg} / \mathrm{L}\right.$ as $\left.\mathrm{CaCO}_{3}\right)$.

\section{Allegheny Portage Railroad National Historic Site}

The remnants of the Allegheny Portage Railroad (ALPO), the first railroad constructed through the Allegheny Mountains in central Pennsylvania and the first railroad tunnel in the United States, are preserved at the Allegheny Portage Railroad
National Historic Site. One bedrock well at the ranger's seasonal-use residence (ALPO) was sampled in July 2011. The well is in Devonian sandstone and shale and had the highest concentrations of dissolved solids $(691 \mathrm{mg} / \mathrm{L})$, chloride $(218 \mathrm{mg} / \mathrm{L})$, magnesium $(39.7 \mathrm{mg} / \mathrm{L})$, and silica $(14.4 \mathrm{mg} / \mathrm{L})$ of all 16 samples collected for this study. Water from ALPO exceeded the USEPA SMCL for dissolved solids $(691 \mathrm{mg} / \mathrm{L})$ and the USEPA HA for sodium $(61.5 \mathrm{mg} / \mathrm{L})$. Elevated concentrations of sodium and chloride $(218 \mathrm{mg} / \mathrm{L})$ contribute to the elevated dissolved solids concentration; the chloride-tobromide ratio $(1,800)$ indicates possible contamination from road deicing salt (Davis and others, 1998). The water from ALPO is very hard $\left(398 \mathrm{mg} / \mathrm{L}\right.$ as $\left.\mathrm{CaCO}_{3}\right)$ and has the highest hardness of all 16 samples. Elevated concentrations of calcium $(93.4 \mathrm{mg} / \mathrm{L})$ and magnesium $(39.7 \mathrm{mg} / \mathrm{L})$ contribute to the hardness of the water.

\section{Johnstown Flood National Monument}

The 164-acre Johnstown Flood National Memorial (JOFL) commemorates the approximately 2,200 people who died in the Johnstown, Pennsylvania, flood on May 31, 1889. The flood was caused by the failure of the South Fork Dam, which spilled the entire contents of Lake Conemaugh into the valley leading to Johnstown. The memorial preserves the remains of the dam and parts of the former Lake Conemaugh bed. One bedrock well at the maintenance facility (JOFL) was sampled in July 2011. The well is in Pennsylvanian shale, siltstone, and sandstone with thin beds of limestone and coal. Water from the JOFL well exceeded the proposed USEPA $\mathrm{MCL}$ for radon $(670 \mathrm{pCi} / \mathrm{L})$. Water from the JOFL was very hard $\left(260 \mathrm{mg} / \mathrm{L}\right.$ as $\left.\mathrm{CaCO}_{3}\right)$. 


\section{Flight 93 National Memorial}

The 817 acre Flight 93 National Memorial (FLNI) is the site of the crash of United Airlines flight 93, which was hijacked by terrorists on September 11, 2001. The memorial was created to honor the 40 passengers and crew who thwarted a potential terrorist attack on the U.S. Capitol. One bedrock well at the west overlook (FLNI) was sampled in July 2011. Water from the well is used for sanitary purposes and not as a source of drinking water. The well is at the site of the former Diamond-T welding facility. The well is in Pennsylvanian sandstone, shale, limestone, and coal. The area surrounding the well is the site of a former coal strip-mining operation. Samples from the FLNI well had the highest concentrations of calcium $(106 \mathrm{mg} / \mathrm{L})$, cobalt $(55.1 \mu \mathrm{g} / \mathrm{L})$, iron $(8,340 \mu \mathrm{g} / \mathrm{L})$, manganese $(3,320 \mu \mathrm{g} / \mathrm{L})$, nickel $(76.2 \mu \mathrm{g} / \mathrm{L})$, and sulfate $(304 \mathrm{mg} / \mathrm{L})$ of all 16 samples collected for this study. Elevated concentrations of these constituents likely are the result of the nearby mining operation. Wood (1996) reported elevated concentrations of calcium, cobalt, iron, manganese, nickel, and sulfate in water samples from mine discharges in eastern Pennsylvania. An acid mine drainage remediation system is located in the park unit. Water from the FLNI well exceeded USEPA SMCLs for $\mathrm{pH}$ (5.9), sulfate $(304 \mathrm{mg} / \mathrm{L})$, dissolved solids $(554 \mathrm{mg} / \mathrm{L})$, iron $(8,340 \mu \mathrm{g} / \mathrm{L})$, and manganese $(3,320 \mu \mathrm{g} / \mathrm{L})$ and is classified as very hard $(369 \mathrm{mg} / \mathrm{L}$ as $\left.\mathrm{CaCO}_{3}\right)$.

\section{Fort Necessity National Battlefield}

The battle at Fort Necessity, which took place on July 3, 1754, was the prelude to the war fought by England and France for control of the North American continent (French and Indian war). The action at Fort Necessity was the first major event in the military career of George Washington. The battle resulted in the surrender of the British under Colonel Washington to the French and Indian forces. A spring at the Fort Necessity National Battlefield (FONE), which serves as the water supply for the 903-acre park, was sampled in July 2011. The spring is in Pennsylvanian shale, and sandstone with thin beds of limestone and coal. Water from the FONE well is dilute and has the lowest dissolved solids concentration $(62 \mathrm{mg} / \mathrm{L})$ and specific conductance $(105 \mu \mathrm{S} / \mathrm{cm})$ of all 16 samples collected for this study and did not meet the USEPA SMCL for $\mathrm{pH}$ (4.8). Water from FONE is classified as soft $\left(49.1 \mathrm{mg} / \mathrm{L}\right.$ as $\left.\mathrm{CaCO}_{3}\right)$.

\section{New River Gorge National River}

The New River Gorge National River (NERI) is a whitewater river that flows through deep canyons in a mountainous region of south-central West Virginia. The park encompasses more than 70,000 acres of land that provides access to scenic and recreational opportunities in an area rich in cultural and natural history. Three bedrock wells, the Sandstone Visitor
Center well (NERI-1), the Dun Glen well (NERI-2), and the Thurmond Depot well (NERI-3), were sampled in August 2011. NERI-1 is in upper Mississippian shale and sandstone, and NERI-2 and NERI-3 are in Lower Pennsylvanian formations of sandstone, shale, and coal. NERI-2 has the highest specific conductance $(1,160 \mu \mathrm{S} / \mathrm{cm})$ and the highest concentration of fluoride $(2.33 \mathrm{mg} / \mathrm{L}$, which exceeds the USEPA SMCL) of all 16 wells sampled in the study. NERI-1 and NERI-2 have concentrations of sodium ( 63.6 and $248 \mathrm{mg} / \mathrm{L}$, respectively) and total dissolved solids (506 and $677 \mathrm{mg} / \mathrm{L}$, respectively) that exceed USEPA HA and SMCL guidelines and radon-222 activity (390 and $420 \mathrm{pCi} / \mathrm{L}$, respectively) that exceeds the proposed USEPA MCL. The concentration of iron $(463 \mu \mathrm{g} / \mathrm{L})$ exceeds the USEPA SMCL at NERI-3. The concentrations of manganese ( 862 and $182 \mu \mathrm{g} / \mathrm{L}$, respectively) exceed the USEPA SMCLs at NERI-1 and NERI-3. Water from NERI-2 has a methane concentration of $30.1 \mathrm{mg} / \mathrm{L}$, which may be derived from coal bed sources; this concentration (greater than $28 \mathrm{mg} / \mathrm{L}$ dissolved in water) may potentially create an explosive condition in the air within the well bore at NERI-2 (Eltschlager and others, 2001). Hydrogen sulfide is present in the water from NERI-2 and NERI-3. The water from NERI-1 is very hard $\left(290 \mathrm{mg} / \mathrm{L}\right.$ as $\left.\mathrm{CaCO}_{3}\right)$ and water from NERI-3 is moderately hard $\left(92.5 \mathrm{mg} / \mathrm{L}\right.$ as $\left.\mathrm{CaCO}_{3}\right)$, whereas water from NERI -2 is soft $\left(3.73 \mathrm{mg} / \mathrm{L}\right.$ as $\left.\mathrm{CaCO}_{3}\right)$.

\section{Upper Delaware National Scenic and Recreational River}

The Upper Delaware Scenic and Recreational River (UPDE) provides recreational access along $73.4 \mathrm{mi}$ of the Delaware River. Sightseeing, boating, camping, hunting, fishing, hiking, and bird watching are popular activities in the river area. Most of the land in this unit is privately owned; the National Park Service owns only 30 acres. Three bedrock wells, the Milanville ranger station well (UPDE-1), the headquarters office well (UPDE-2), and the Zane Grey House well (UPDE-3), were sampled in August 2011. The wells are in Devonian sandstone, siltstone, and shale with some conglomerate. Water from UPDE-1, UPDE-2, and UPDE-3 had the highest radon-222 activities $(3,030,1,310$, and $1,210 \mathrm{pCi} / \mathrm{L}$, respectively) of all 16 samples, and all exceeded the proposed USEPA MCL. Water from UPDE-1 and UPDE-2 exceeded the USEPA SMCL for $\mathrm{pH}$ (5.7 and 5.5, respectively). Water from UPDE-3 had the highest concentration of arsenic $(32.3 \mu \mathrm{g} / \mathrm{L})$ of all 16 samples and exceeded the USEPA MCL of $10 \mu \mathrm{g} / \mathrm{L}$. Water from UPDE-3 also exceeded the USEPA HA for sodium $(68.8 \mathrm{mg} / \mathrm{L})$ and the USEPA SMCL for manganese $(95.1 \mu \mathrm{g} / \mathrm{L})$. Hydrogen sulfide is present in water from UPDE-3. Water from UPDE-3 is used for sanitary purposes and is not used as a source of drinking water. Water from all three wells is classified as soft. 


\section{Saratoga National Historical Park}

Saratoga National Historical Park (SARA), an area of 3,400 acres in northeastern New York, comprises three separate historic sites, the battlefield area, the Schuyler House, and the Saratoga Monument. The Revolutionary War battles at Saratoga in 1777 were major American victories that assured international recognition and helped secure the independence of the United States. Three wells exist at the park, one at the visitor center and two at battlefield tour stop 8; the selected sample site was well number 1 at tour stop 8 (SARA), which is screened at a $28-\mathrm{ft}$ depth in an unconsolidated glacial-lake sand aquifer. The well sample, collected in August 2011, contains among the lowest dissolved solids and nutrient concentrations of all wells sampled in the study, and the water meets all drinking-water standards for the sampled constituents.

\section{Martin Van Buren National Historic Site}

The Martin Van Buren National Historic Site (MAVA) preserves Lindenwald, Van Buren's historic home and grounds where he lived after having served as eighth President of the United States (1837-1841) until his death. The 40-acre site is about 30 mi southeast of Albany in eastern New York. Two bedrock wells, the headquarters office well (MAVA-1) and the maintenance facility well (MAVA-2), completed in lower Ordovician shale and siltstone were sampled in August 2011. The results for samples from both wells meet all drinkingwater standards for the sampled constituents. Water from MAVA-1, however, contains hydrogen sulfide; it also has the highest barium concentration of all 16 samples $(1,050 \mu \mathrm{g} / \mathrm{L})$, which is below the SMCL of $2,000 \mu \mathrm{g} / \mathrm{L}$. The water from MAVA-1 is soft ( $34 \mathrm{mg} / \mathrm{L}$ as $\mathrm{CaCO}_{3}$ ), whereas the water from MAVA-2 is very hard $\left(254 \mathrm{mg} / \mathrm{L}\right.$ as $\left.\mathrm{CaCO}_{3}\right)$. This park lies within a designated national heritage area near the eastern shore of the Hudson River, which places it just outside of the shale gas play area. The park was included in the waterquality assessment to establish a baseline for this historic site's groundwater resources.

\section{Summary}

New developments in horizontal drilling for natural gas and increasing prices of natural gas have made the large natural gas resource of the Marcellus Shale and Utica Shale formations an exploitable resource in the northeastern United States. To produce natural gas from a low-permeability rock such as shale, permeable flowpaths for the gas to move to the well bore must be created in the gas-bearing formations through the use of high-pressure hydraulic fracturing. A single hydraulic fracturing treatment for a gas well drilled horizontally in shale uses substantial volumes of water and chemical additives, often in excess of 1 million gallons, and much of the injected fluid may flow back to the surface through the well bore and casing. The injected fluids and natural brine in the shale that do flow to the surface can have elevated levels of total dissolved solids and naturally occurring radioactive material. Water-supply wells and springs within national park units in the shale gas play areas may be susceptible to potential contamination because many national park units and adjacent lands are within some of the most desirable locations for drilling. The objective of this study was to characterize the existing water quality and radiochemistry of national park unit water-supply wells and springs before drilling activities commence in the most desirable shale gas play areas of New York, Pennsylvania, and West Virginia. This water-quality characterization of the national park wells and springs provides a baseline of information for chemical and radiochemical constituents that could be affected if contamination from drilling and gas development occurs. Two production wells also were sampled in one national park outside the gas play area in an area vulnerable to contamination from increased urbanization.

A total of 16 groundwater sources were selected for sampling. Water samples were collected from 15 production wells and 1 spring at 9 national park units in New York, Pennsylvania, and West Virginia in July and August 2011 and analyzed to characterize the chemical quality. Samples were analyzed for 53 constituents, including nutrients, major inorganic constituents, trace elements, chemical oxygen demand, radioactivity, and dissolved gases, including methane and radon-222.

Scientists from the U.S. Geological Survey sampled the individual water-supply sources for the national park units using standard USGS field-sampling protocols. Samples were collected from each well at an untreated tap, typically at a pressure tank and before any filtration, water softening, or bacteriological treatment. Thirteen of the wells were constructed in bedrock aquifers, with well depths that ranged from 193 to 400 feet (ft). One well tapped water through a shallow well screen (28-ft-deep) that was set in an unconsolidated glaciallake sand aquifer. One well was cased to $192 \mathrm{ft}$ and open to a sand and gravel deposit. In addition, one spring used as a source of water supply was sampled.

The quality of the sampled groundwater was generally within U.S. Environmental Protection Agency (USEPA) guidelines, although in some samples, the concentrations of certain constituents exceeded Federal drinking-water standards. In general, most of the water-quality problems involve aesthetic considerations, such as taste or odor from excessive dissolved solids, iron, manganese, sodium, and sulfate that develop from natural interactions of water and rock minerals in the subsurface. The results of laboratory analysis indicate that groundwater used for water supply at the selected national park units is generally of acceptable quality, although concentrations of some constituents exceeded at least one drinkingwater standard at several wells.

Specific conductance of the samples, which is an indication of the dissolved mineral content, ranged from 
105 to 1,160 microsiemens per centimeter at 25 degrees Celsius. Calcium and magnesium contribute to water hardness, and 5 of the 16 samples had hardness greater than 180 milligrams per liter $(\mathrm{mg} / \mathrm{L})$, which is classified as very hard. Nutrient concentrations were low, and no sample had a detectable chemical oxygen demand, indicating that sources of organic waste are minimal at the sampled sites. Gross-alpha and gross-beta radioactivity levels were low at all sites; nine well sites had nondetectable gross-alpha activity, seven sites had nondetectable gross-beta activity, and maximum activities were 3.6 and 3.3 picocuries per liter $(\mathrm{pCi} / \mathrm{L})$, respectively. The dissolved methane gas concentrations ranged from nondetected to $30.1 \mathrm{mg} / \mathrm{L}$. The methane concentrations, except for the one sample with a concentration of $30.1 \mathrm{mg} / \mathrm{L}$, are considered to be within ambient background levels.

Nine analytes were detected in concentrations that exceeded Federal drinking-water standards. The $\mathrm{pH}$, which is a measure of acidity (hydrogen ion activity), ranged from 4.8 to 8.4 , and in 5 of the 16 samples, the $\mathrm{pH}$ values were outside the accepted USEPA secondary maximum contaminant level (SMCL) range of 6.5 to 8.5. One sample had an arsenic concentration that exceeded the USEPA maximum contaminant level of 10 micrograms per liter $(\mu \mathrm{g} / \mathrm{L})$. The concentration of total dissolved solids exceeded the SMCL of $500 \mathrm{mg} / \mathrm{L}$ in four samples. The sulfate concentration exceeded the SMCL of $250 \mathrm{mg} / \mathrm{L}$ in one sample, and the fluoride concentration exceeded the SMCL of $2 \mathrm{mg} / \mathrm{L}$ in one sample. The USEPA health advisory for sodium, which recommends that concentrations in drinking water not exceed $60 \mathrm{mg} / \mathrm{L}$ to minimize the taste, was exceeded in four samples. Iron concentrations exceeded the SMCL of $300 \mu \mathrm{g} / \mathrm{L}$ in two samples, and manganese concentrations exceeded the SMCL of $50 \mu \mathrm{g} / \mathrm{L}$ in five samples. Radon-222 concentrations exceeded the proposed USEPA MCL of $300 \mathrm{pCi} / \mathrm{L}$ in eight samples.

\section{References Cited}

Berg, T.M., Edmunds, W.E., Geyer, A.R., and others (compilers), 1980, Geologic map of Pennsylvania (2d ed.): Pennsylvania Geological Survey Series 4, Map 1, 3 sheets, scale 1:250,000.

Broughton, J.G., Fisher, D.W., Isachsen, Y.W., Rickard, L.V., and Offield, T.W., 1962, The geology of New York state: Albany, New York State Geological Survey Map and Chart Series no. 5, 5 sheets, scale 1:250,000.

Cardwell, D.H., Erwin, R.B., and Woodward, H.P., 1968, Geologic map of West Virginia: West Virginia Geological Survey Map 1, 1 sheet, scale 1:250,000.

Davis, S.N., Whittemore, D.O., and Fabryka-Martin, June, 1998, Uses of chloride/bromide ratios in studies of potable water: Groundwater, v. 36, p. 338-350.
Eltschlager, K.K., Hawkins, J.W., Ehler, W.C., and Baldassare, Fred, 2001, Technical measures for the investigation and mitigation of fugitive methane hazards in areas of coal mining: Office of Surface Mining Reclamation and Enforcement, $125 \mathrm{p}$.

Harper, J.A., 2008, The Marcellus shale-An old "new" gas reservoir: Pennsylvania Geology, v. 38, no. 1, p. 2-13.

Harper, J.A., and Kostelnik, Jaime, 2010, The Marcellus shale play in Pennsylvania: Pennsylvania Geological Survey, accessed December 13, 2011, at http://www.denr.state.pa.us/ topogeo/oilandgas/Marcellus.pdf.

Hayes, Tom, 2011, Characterization of Marcellus and Barnett Shale flowback waters and technology development for water reuse: U.S. Environmental Protection Agency, Hydraulic Fracturing Technical Workshop no. 4, Arlington, Virginia, March 30, 2011, presentation and notes, $70 \mathrm{p}$., accessed July 26, 2012, at http://www.epa.gov/hfstudy/ 12_Hayes_-_Marcellus_Flowback_Reuse_508.pdf.

Hem, J.D., 1985, Study and interpretation of the chemical characteristics of natural water (3d ed.): U.S. Geological Survey Water-Supply Paper 2254, 264 p.

Kargbo, D.M., Wilhelm, R.G., and Campbell, D.J., 2010, Natural gas plays in the Marcellus shale - Challenges and potential opportunities: Environmental Science and Technology, v. 44, p. 5679-5684.

Keister, Timothy, 2010, Marcellus hydrofracture flowback and production wastewater treatment, recycle, and disposal technologies: Susquehanna River Heartland Coalition for Environmental Studies and Foundation for Pennsylvania's Water Sheds and Rivers, The Science of Marcellus Shale, Williamsport, Pennsylvania, January 29, 2010, presentation, 8 p., accessed July 26, 2012, at http://energy.wilkes.edu/ PDFFiles/Library/The_Science_of_Marcellus_Shale_ Wastewater.pdf.

Kerr, R.A., 2010, Natural gas from shale bursts onto the scene: Science, v. 328, p. 1624-1626.

Martin, J.P., Hill, D.G., and Lombardi, T.E., 2004, Fractured shale gas potential in New York: Northeastern Geology and Environmental Science, v. 26, nos. 1-2, p. 57-78.

Molofsky, L.J., Connor, J.A., Farhat, S.K., Wylie, A.S., Jr., and Wagner, Tom, 2011, Methane in Pennsylvania water wells unrelated to Marcellus shale fracturing: Oil and Gas Journal, v. 109, no. 49, 12 p. 
New York State Department of Environmental Conservation, 2011, Radiological data-Production brine from NYS Marcellus wells, appendix 13 of Revised draftSupplemental generic environmental impact statement on the oil, gas and solution mining regulatory program: New York State Department of Environmental Conservation, accessed December 7, 2011, at http://www.dec.ny.gov/docs/ materials_minerals_pdf/rdsgeisapp1140911.pdf.

Osborn, S.G., Avner, Vengosh, Warner, N.R., and Jackson, R.B., 2011, Methane contamination of drinking water accompanying gas-well drilling and hydraulic fracturing: Proceedings of the National Academy of Science, v. 108, p. 8172-8176.

Palmerton Group, Inc., 2011, Marcellus Shale gas frack flowback water study: Palmerton Group, Inc., accessed December 7, 2011, at http://www.palmertongroup.com/services/ marcellus-shale-gas/frac-flow-back-water-study.asp.

Pennsylvania Department of Environmental Protection, 2008, DEP investigates source of elevated total dissolved solids in Monongahela River: Harrisburg, Pa., Pennsylvania Department of Environmental Protection press release, October 22, $4 \mathrm{p}$.

Sevon, W.D., 2000, Physiographic provinces of Pennsylvania: Pennsylvania Geological Survey, Series 4, Map 13, 1 sheet.

Soeder, D.J., and Kappel, W.M., 2009, Water resources and natural gas production from the Marcellus shale: U.S. Geological Survey Fact Sheet 2009-3032, 6 p.

U.S. Environmental Protection Agency, 2002, Drinking-water advisory - Consumer acceptability advice and health effects analysis on sodium: U.S. Environmental Protection Agency EPA 822-R-02-032, $34 \mathrm{p}$.

U.S. Environmental Protection Agency, 2004, Proposed radon in drinking water rule: U.S. Environmental Protection Agency, accessed November 13, 2011, at http://www.epa. gov/safewater/radon/proposal.html.
U.S. Environmental Protection Agency, 2006, Drinking water standards and health advisories: U.S. Environmental Protection Agency EPA 822-R-06-013, 12 p.

U.S. Environmental Protection Agency, 2011a, Drinking water contaminants - National primary drinking water regulations: U.S. Environmental Protection Agency, accessed November 13, 2011, at http://water.epa.gov/drink/ contaminants/index.cfm.

U.S. Environmental Protection Agency, 2011b, Hydraulic fracturing: U.S. Environmental Protection Agency, accessed November 13, 2011, at http://water.epa.gov/type/ groundwater/uic/class2/hydraulicfracturing/.

U.S. Geological Survey, 2009, Analytical procedures for dissolved gas: U.S. Geological Survey, accessed November 13, 2011, http://water.usgs.gov/lab/dissolved-gas/lab/ analytical_procedures/.

U.S. Geological Survey, 2011, National Water Quality Laboratory: U.S. Geological Survey, accessed November 13, 2011, at http://nwql.usgs.gov/.

U.S. Geological Survey, 2012, USGS water data for the nation: U.S. Geological Survey, accessed April 2, 2012, at http://waterdata.usgs.gov/nwis.

U.S. Geological Survey, [variously dated], National field manual for the collection of water-quality data: U.S. Geological Survey Techniques of Water-Resources Investigations, book 9, chap. A1-A9, accessed November 13, 2011, at http://pubs.water.usgs.gov/twri9A/.

Wilde, F.D., Radtke, D.B., Gibs, Jacob, and Iwatsubo, R.T., eds., 2004, Processing of water samples: U.S. Geological Survey Techniques of Water-Resources Investigations, book 9 , chap. A5, [variously paginated].

Wood, C.R., 1996, Water quality of large discharges from mines in the anthracite region of eastern Pennsylvania: U.S. Geological Survey Water-Resources Investigations Report 95-4243, 68 p., accessed November 13, 2011, at http://pubs.usgs.gov/wri/1995/4243/report.pdf. 
Tables 6-9 
Table 6. Physical properties and dissolved gas concentrations for samples from 15 wells and 1 spring at national park units within the Marcellus Shale and Utica Shale in New York, Pennsylvania, and West Virginia in 2011.

[Locations are shown in figure 1; site information is listed in table $1 . \mu \mathrm{S} / \mathrm{cm}$, microsiemens per centimeter at $25^{\circ} \mathrm{C} ; \mathrm{mg} / \mathrm{L}$, milligrams per liter; $<$, less than; (00400), USGS National Water Information System (NWIS) parameter code. Bold values exceed drinking-water standard]

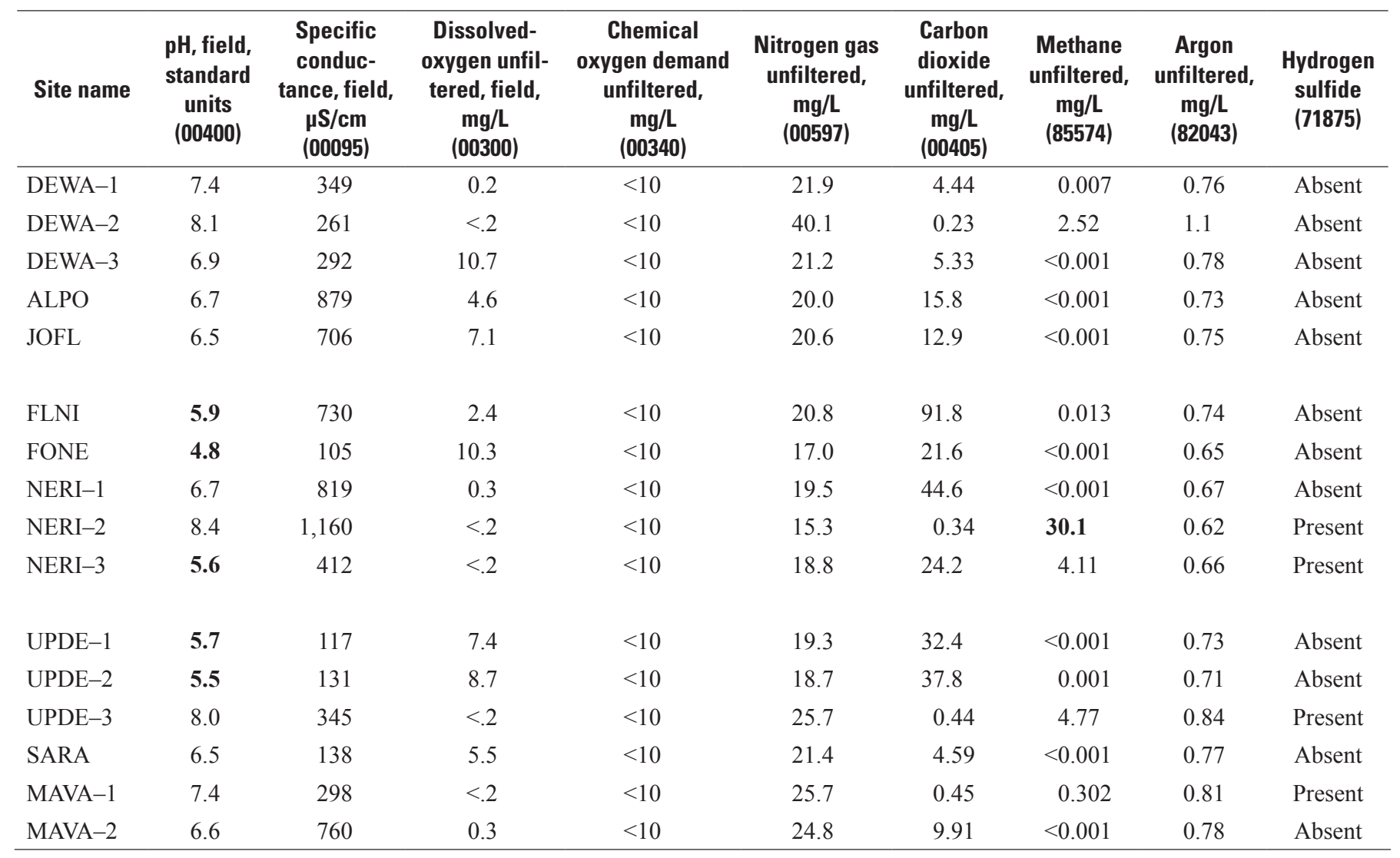


Table 7. Concentrations of inorganic constituents in samples from 15 wells and 1 spring at national park units within the Marcellus Shale and Utica Shale in New York, Pennsylvania, and West Virginia in 2011.

[Well locations are shown in figure 1; site information is listed in table $1 . \mathrm{mg} / \mathrm{L}$, milligrams per liter; $\mathrm{CaCO}_{3}$, calcium carbonate; (00900), USGS National Water Information System (NWIS) parameter code. Bold values exceed drinking-water standard]

\begin{tabular}{lcccccc}
\hline Site name & $\begin{array}{c}\text { Hardness, } \\
\text { filtered, } \\
\mathbf{m g} / \mathbf{L} \text { as CaCo } \\
\mathbf{( 0 0 9 0 0 )}\end{array}$ & $\begin{array}{c}\text { Calcium, } \\
\text { filtered, } \\
\mathbf{m g} / \mathbf{L} \\
\mathbf{( 0 0 9 1 5 )}\end{array}$ & $\begin{array}{c}\text { Magnesium, } \\
\text { filtered, } \\
\mathbf{m g} / \mathbf{L} \\
\mathbf{( 0 0 9 2 5 )}\end{array}$ & $\begin{array}{c}\text { Potassium, } \\
\text { filtered, } \\
\mathbf{m g} / \mathbf{L} \\
\mathbf{( 0 0 9 3 5 )}\end{array}$ & $\begin{array}{c}\text { Sodium, } \\
\text { filtered, } \\
\mathbf{m g} / \mathbf{L} \\
\mathbf{( 0 0 9 3 0 )}\end{array}$ & $\begin{array}{c}\text { Alkalinity, } \\
\text { filtered, } \\
\mathbf{m g} / \mathbf{L} \text { as CaCo } \\
\text { (29801) }\end{array}$ \\
\hline DEWA-1 & 165 & 47.5 & 11.2 & 0.43 & 6.85 & 145 \\
DEWA-2 & 17.4 & 5.22 & 0.951 & 0.33 & 54.6 & 127 \\
DEWA-3 & 81.9 & 27.3 & 3.31 & 0.55 & 22.5 & 48 \\
ALPO & 398 & 93.4 & 39.7 & 1.17 & $\mathbf{6 1 . 5}$ & 216 \\
JOFL & 260 & 74.0 & 18.2 & 1.34 & 53.4 & 152 \\
& & & & & & \\
FLNI & 369 & 106 & 25.0 & 1.20 & 4.91 & 41 \\
FONE & 49.1 & 13.0 & 4.03 & 0.78 & 1.34 & 41 \\
NERI-1 & 290 & 75.6 & 24.3 & 0.85 & $\mathbf{6 3 . 6}$ & 220 \\
NERI-2 & 3.73 & 1.04 & 0.253 & 0.39 & $\mathbf{2 4 8}$ & 347 \\
NERI-3 & 92.5 & 24.8 & 7.30 & 1.04 & 51.1 & 144 \\
& & & & & & \\
UPDE-1 & 45.0 & 13.0 & 2.99 & 0.96 & 3.51 & 38 \\
UPDE-2 & 34.6 & 8.99 & 2.92 & 0.87 & 9.35 & 16 \\
UPDE-3 & 19.2 & 4.85 & 1.56 & 0.80 & $\mathbf{6 8 . 8}$ & 110 \\
SARA & 60.8 & 17.8 & 3.96 & 0.90 & 1.69 & 61 \\
MAVA-1 & 34.0 & 7.75 & 3.12 & 3.06 & 51.8 & 124 \\
MAVA-2 & 254 & 72.9 & 17.1 & 2.06 & 49.3 & 183 \\
\hline \hline
\end{tabular}


Table 7. Concentrations of inorganic constituents in samples from 15 wells and 1 spring at national park units within the Marcellus Shale and Utica Shale in New York, Pennsylvania, and West Virginia in 2011._Continued

[Well locations are shown in figure 1; site information is listed in table $1 . \mathrm{mg} / \mathrm{L}$, milligrams per liter; $\mathrm{CaCO}_{3}$, calcium carbonate; $\mathrm{C}$, Celsius; <, less than; (29805), USGS National Water Information System (NWIS) parameter code. Bold values exceed drinking-water standard]

\begin{tabular}{|c|c|c|c|c|c|c|c|}
\hline Site name & $\begin{array}{c}\text { Bicarbonate, } \\
\text { filtered, } \\
\mathrm{mg} / \mathrm{L} \text { as } \mathrm{CaCO}_{3} \\
\text { (29805) }\end{array}$ & $\begin{array}{c}\text { Bromide } \\
\text { filtered, } \\
\text { mg/L } \\
(71870)\end{array}$ & $\begin{array}{c}\text { Chloride, } \\
\text { filtered, } \\
\text { mg/L } \\
(00940)\end{array}$ & $\begin{array}{c}\text { Fluoride, } \\
\text { filtered, } \\
\text { mg/L } \\
(00950)\end{array}$ & $\begin{array}{c}\text { Silica, } \\
\text { filtered, } \\
\mathrm{mg} / \mathrm{L} \\
(00955)\end{array}$ & $\begin{array}{c}\text { Sulfate, } \\
\text { filtered, } \\
\mathrm{mg} / \mathrm{L} \\
(00945)\end{array}$ & $\begin{array}{l}\text { Dissolved solids } \\
\text { dried at } 180^{\circ} \mathrm{C}, \\
\text { filtered, } \\
\mathrm{mg} / \mathrm{L} \\
(70300)\end{array}$ \\
\hline DEWA-1 & 177 & 0.03 & 9.89 & 0.05 & 11.1 & 24.4 & 195 \\
\hline DEWA-2 & 155 & 0.02 & 9.96 & 0.28 & 8.04 & 1.78 & 156 \\
\hline DEWA-3 & 59 & 0.02 & 52.4 & $<.04$ & 8.15 & 11.2 & 171 \\
\hline ALPO & 264 & 0.12 & 218 & 0.17 & 14.4 & 29.7 & 691 \\
\hline JOFL & 185 & 0.05 & 149 & 0.16 & 10.2 & 25.1 & 480 \\
\hline FLNI & 50 & 0.06 & 19.7 & $<.04$ & 7.29 & 304 & 554 \\
\hline FONE & 50 & 0.01 & 3.17 & $<.04$ & 6.83 & 8.43 & 62 \\
\hline NERI-1 & 268 & 0.13 & 50.7 & 0.13 & 13.1 & 128 & 506 \\
\hline NERI-2 & 423 & 1.52 & 151 & 2.33 & 7.35 & 0.27 & 677 \\
\hline NERI-3 & 176 & 0.30 & 34.6 & 0.24 & 12.3 & 6.73 & 231 \\
\hline UPDE-1 & 46 & $<.01$ & 5.58 & $<.04$ & 9.68 & 9.55 & 82 \\
\hline UPDE-2 & 20 & $<.01$ & 19.0 & $<.04$ & 8.82 & 10.0 & 75 \\
\hline UPDE-3 & 134 & 0.38 & 39.0 & 0.54 & 7.11 & 0.12 & 193 \\
\hline SARA & 74 & $<.01$ & 0.59 & 0.06 & 12.8 & 6.63 & 79 \\
\hline MAVA-1 & 151 & $<.01$ & 16.8 & 0.45 & 10.6 & 3.13 & 181 \\
\hline MAVA-2 & 223 & 0.03 & 110 & 0.09 & 10.7 & 35.2 & 414 \\
\hline
\end{tabular}

${ }^{1}$ Fixed-endpoint titration at $\mathrm{pH} 4.5$.

${ }^{2}$ Calculated from alkalinity. 
Table 8. Concentrations of nutrients in samples from 15 wells and 1 spring at national park units within the Marcellus Shale and Utica Shale in New York, Pennsylvania, and West Virginia in 2011.

[Well locations are shown in figure 1; site information is listed in table 1. $\mathrm{mg} / \mathrm{L}$, milligrams per liter; $\mathrm{N}$, nitrogen; P, phosphorus; <, less than; (00608), USGS National Water Information System (NWIS) parameter code]

\begin{tabular}{lccccc}
\hline \multicolumn{1}{c}{ Site name } & $\begin{array}{c}\text { Ammonia, } \\
\text { filtered, } \\
\mathbf{m g / L} \text { as N } \\
\mathbf{( 0 0 6 0 8 )}\end{array}$ & $\begin{array}{c}\text { Nitrate plus } \\
\text { nitrite, filtered, } \\
\mathbf{m g} / \mathbf{L} \text { as N } \\
\mathbf{( 0 0 6 3 1 )}\end{array}$ & $\begin{array}{c}\text { Nitrite, filtered, } \\
\mathbf{m g} / \mathbf{L} \text { as N } \\
\mathbf{( 0 0 6 1 3 )}\end{array}$ & $\begin{array}{c}\text { Orthophosphate, } \\
\text { filtered, } \\
\mathbf{m g} / \mathbf{L} \text { as } \mathbf{P} \\
\mathbf{( 0 0 6 7 1 )}\end{array}$ & $\begin{array}{c}\text { Total nitrogen } \\
\text { filtered, } \\
\mathbf{m g} / \mathbf{L} \text { as N } \\
\mathbf{( 6 2 8 5 4 )}\end{array}$ \\
\hline DEWA-1 & 0.082 & $<.02$ & $<.001$ & 0.011 & 0.06 \\
DEWA-2 & 0.285 & $<.02$ & $<.001$ & 0.032 & 0.29 \\
DEWA-3 & $<.010$ & 0.23 & $<.001$ & 0.007 & 0.29 \\
ALPO & $<.010$ & 0.16 & $<.001$ & 0.012 & 0.17 \\
JOFL & $<.010$ & 0.80 & $<.001$ & 0.010 & 0.81 \\
& & & & & \\
FLNI & 0.037 & $<.02$ & $<.001$ & 0.006 & 0.06 \\
FONE & $<.010$ & 0.13 & $<.001$ & 0.012 & 0.14 \\
NERI-1 & 0.074 & 0.04 & 0.003 & 0.005 & 0.07 \\
NERI-2 & 0.147 & $<.02$ & $<.001$ & 0.057 & 0.06 \\
NERI-3 & 0.122 & $<.02$ & $<.001$ & 0.040 & $<.05$ \\
& & & & & \\
UPDE-1 & $<.010$ & 0.09 & $<.001$ & 0.018 & 0.08 \\
UPDE-2 & $<.010$ & 1.16 & $<.001$ & 0.008 & 1.05 \\
UPDE-3 & 0.060 & $<.02$ & $<.001$ & 0.176 & $<.05$ \\
SARA & $<.010$ & 0.07 & $<.001$ & 0.022 & $<.05$ \\
MAVA-1 & 0.491 & $<.02$ & $<.001$ & 0.006 & 0.48 \\
MAVA-2 & 0.032 & 0.15 & $<.001$ & 0.005 & 0.15 \\
\hline
\end{tabular}


Table 9. Concentrations of trace elements and radioactivity in samples from 15 wells and 1 spring at national park units within the Marcellus Shale and Utica Shale in New York, Pennsylvania, and West Virginia in 2011.

[Well locations are shown in figure 1; site information is listed in table 1. $\mu \mathrm{g} / \mathrm{L}$, micrograms per liter; <, less than; (01106), USGS National Water Information System (NWIS) parameter code. Bold values exceed drinking-water standard]

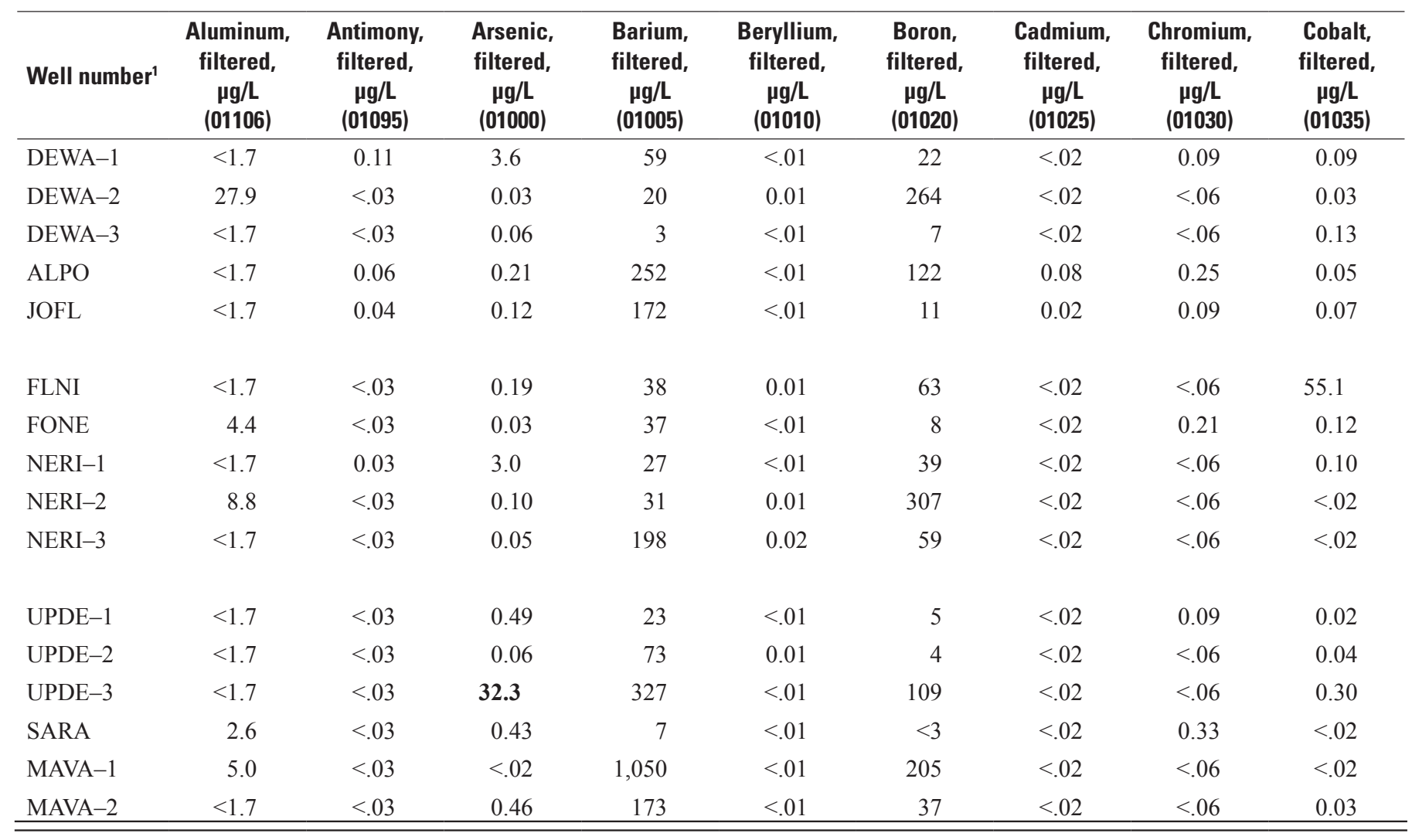


Table 9. Concentrations of trace elements and radioactivity in samples from 15 wells and 1 spring at national park units within the Marcellus Shale and Utica Shale in New York, Pennsylvania, and West Virginia in 2011._Continued

[Well locations are shown in figure 1; site information is listed in table 1. $\mu \mathrm{g} / \mathrm{L}$, micrograms per liter; <, less than; (01040), USGS National Water Information System (NWIS) parameter code. Bold values exceed drinking-water standard]

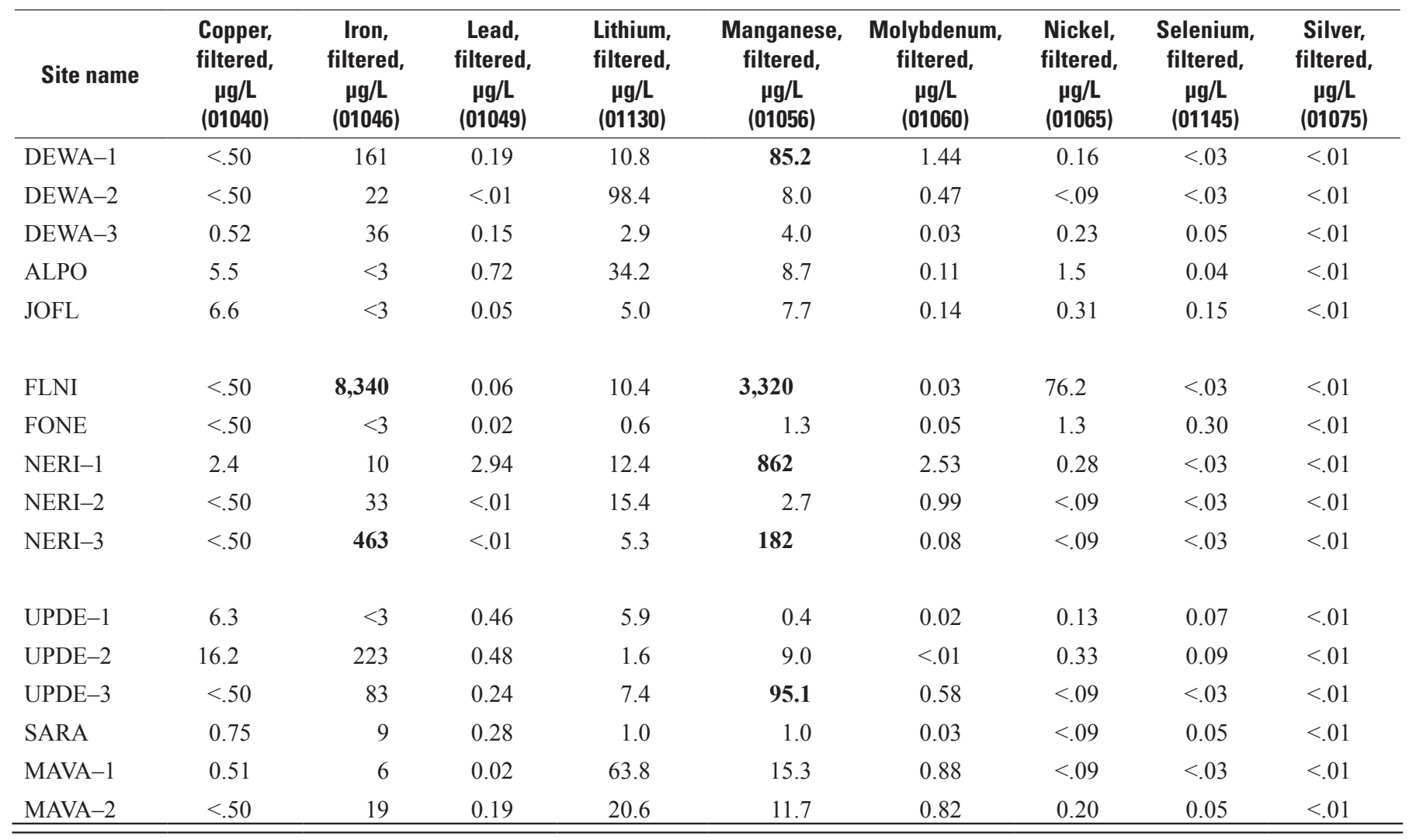


Table 9. Concentrations of trace elements and radioactivity in samples from 15 wells and 1 spring at national park units within the Marcellus Shale and Utica Shale in New York, Pennsylvania, and West Virginia in 2011._Continued

[Well locations are shown in figure 1; site information is listed in table 1. $\mu \mathrm{g} / \mathrm{L}$, micrograms per liter; <, less than; (01080), USGS National Water Information System (NWIS) parameter code. Bold values exceed drinking-water standard]

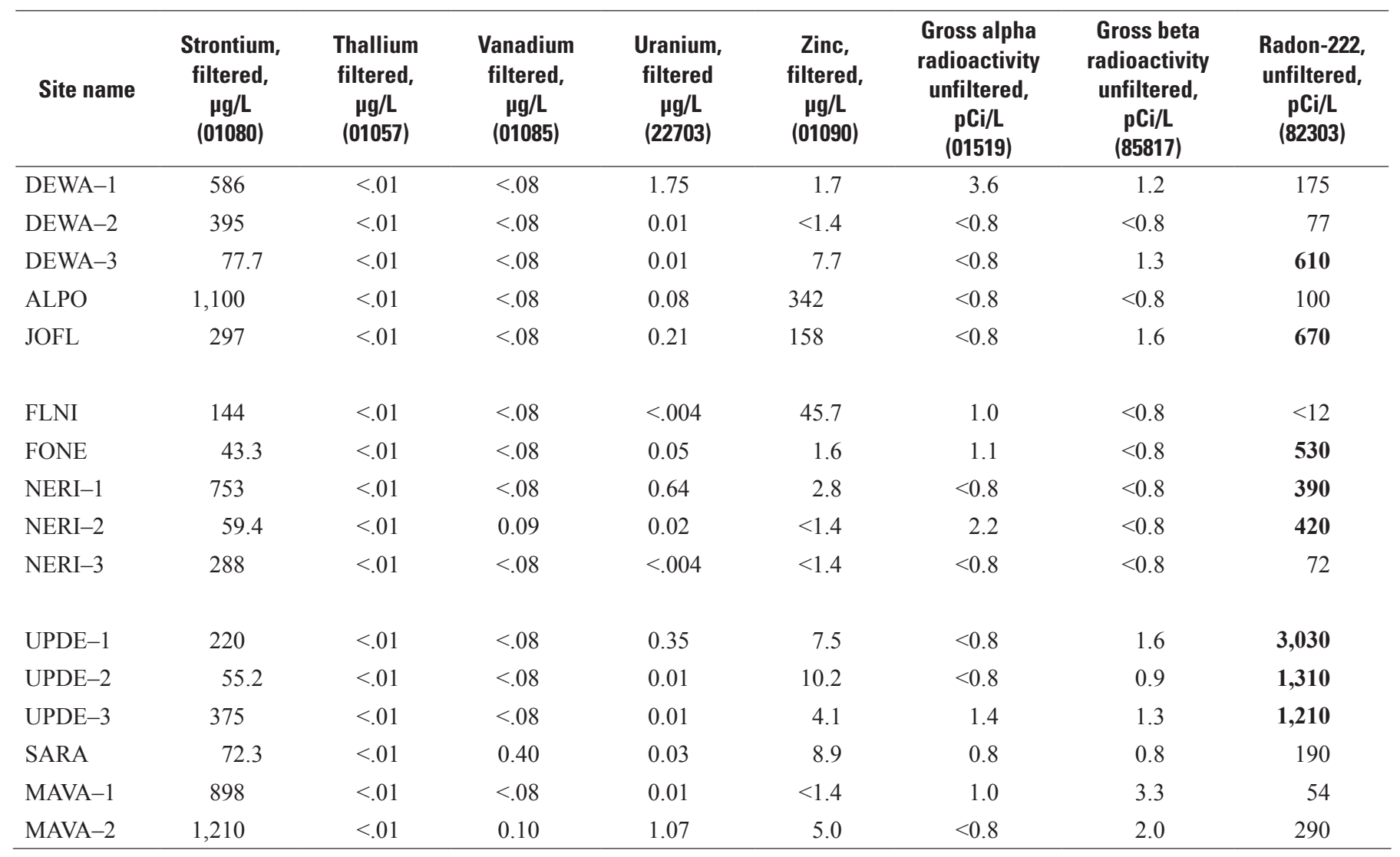


Prepared by the Pembroke Publishing Service Center.

For additional information write to:

New York Water Science Center

U.S. Geological Survey

30 Brown Rd.

Ithaca, NY 14850

Information requests:

(518) 285-5602

or visit our Web site at:

http://ny.water.usgs.gov/ 
通 